\title{
Sistem Deteksi Pra-Kanker Serviks dengan Pengolahan Citra Hasil Inspeksi Visual Asam Asetat
}

\author{
The Cervical Precancer Detection System with the Image processing of Visual \\ Inspection Acetic Acid Result
}

\author{
Hilman Fauzi ${ }^{1}$, Galih Surya ${ }^{2}$, Rita Magdalena ${ }^{3}$, Ali Budi Harsono ${ }^{4}$, Tauhid Nur Azhar ${ }^{5}$ \\ ${ }^{1,2,3}$ Teknik Telekomunikasi Fakultas Teknik Elektro Universitas Telkom, Bandung \\ ${ }^{4}$ Fakultas Kedokteran Universitas Padjadjaran, Bandung \\ ${ }^{5}$ Fakultas Kedokteran Universitas Islam Bandung, Bandung \\ E-mail: 'hilmanfauzitsp@telkomuniversity.ac.id, ${ }^{2}$ gasur.galih@gmail.com, \\ 3ritamagdalena@telkomuniversity.ac.id, ${ }^{4}$ alibudih@yahoo.com, ${ }^{5}$ tauhid.nurazhar@gmail.com
}

\begin{abstract}
Abstrak
Kanker serviks merupakan penyakit mematikan nomor satu di Indonesia dengan angka kematian tertinggi pada wanita. Berbagai upaya untuk mengurangi angka kematian wanita Indonesia akibat kanker serviks telah banyak dilakukan, salah satunya dengan melakukan screening kanker menggunakan tes inspeksi visual asam asetat (tes IVA). Tes ini merupakan upaya screening untuk mengetahui pra-cancer atau invasive cancer pada kanker serviks dengan memunculkan Acetowhite Epithelium Zone (AEZ) yang dapat dikategorikan sebagai lesi IVA positif maupun lesi jinak. Umumnya, AEZ dapat dilihat dengan kasat mata yang memerlukan keahlian khusus sehingga hasil pengamatannya akan bersifat subjektif dan bergantung pada pengalaman operator. Selain itu, utilitas pemeriksaan kanker serviks ini pun dinilai terbatas dikarenakan sedikitnya jumlah operator ahli yang terlatih. Pada penelitian ini, lesi pra-kanker serviks dikuantifikasi dengan pengolahan citra digital. Citra yang digunakan adalah citra hasil inspeksi visual asam asetat atau citra area mulut rahim yang telah diolesi oleh asam asetat dan dinyatakan terdapat sambungan skuamosa kolumnar (SSK) positif. Kuantifikasi citra lesi pra-kanker serviks dilakukan dengan menggunakan metode standarisasi karakter warna citra pada RGB dan HSV. Pengujian system deteksi lesi pra-kanker serviks diukur dengan menggunakan parameter akurasi, sensitivitas dan spesifisitas terhadap pengaruh tingkat kecerahan dan mean filter. Melalui penelitian ini didapatkan klasifikasi citra tes IVA beserta area lesi IVA positif yang optimal dengan tingkat akurasi $81 \%$, nilai sensitivitas $78 \%$ dan nilai spesifisitas $84 \%$. Performa system sangat dipengaruhi oleh ketajaman dan efek pencahayaan pada citra, baik itu intensitas cahaya, efek bayangan, maupun efek pantulan cahaya.
\end{abstract}

Kata kunci: Kanker Serviks, IVA, AEZ, SSK, Citra Digital

\begin{abstract}
Cervical cancer is the deadliest disease for Indonesian women. Various efforts have done to reduce the death rate of Indonesian women due to cervical cancer, one of which is by screening for cancer using an acetic acid visual inspection test (AVI). This test is a pre-cervical cancer screening by giving rise to the Acetowhite Epithelium Zone (AEZ). In general, AEZ can be seen by the naked eye that requires specific expertise. It makes the AEZ observations are subjective and depend on the operator experience. Besides, the utility of cervical cancer screening is considered limited due to the small number of trained expert operators. In this study, cervical pre-cancer lesions were quantified by digital image processing. The images used are the acetic acid visual inspection results images or the image of the cervix region that has been smeared with acetic acid and stated that there is a positive columnar squamous junction (CSJ). Image
\end{abstract}


quantification of cervical pre-cancer lesions was performed using the standardization method of image color characters on RGB and HSV. The test for cervical pre-cancer lesion detection system was measured using the parameters of accuracy, sensitivity, and specificity to the effect of the brightness level and the mean filter. Based on the results of the study, the optimal performance of the IVA detection system was obtained with an accuracy of $81 \%$, sensitivity of $78 \%$, and specificity of $84 \%$. The system performance was greatly influenced by sharpness and lighting effects on the image such as light intensity, shadow effects, and light reflection effects.

\section{Keyword: Cervical Cancer, AVI, AEZ, CSJ, Digital Image}

\section{PENDAHULUAN}

Penyakit kanker serviks merupakan penyakit kanker dengan prevalensi tertinggi di Indonesia pada Tahun 2013, yaitu 0,8 \%o atau sekitar 98.692 kasus[1]. Diseluruh dunia, menurut WHO (World Health Organization) terdapat 530.000 kasus baru pada tahun 2012 yang mewakili 7,5\% dari semua kematian akibat kanker pada wanita. Data dari Global Burden Cancer (GLOBOCAN), International Agency for Research on Cancer (IARC) menunjukkan pada tahun 2012 insidens kanker serviks di seluruh dunia sebesar 16 per 100.000 penduduk. Berdasarkan data dari World Health Organization (WHO) pada tahun 2014 terdapat lebih dari 528.000 kasus baru dan 266.000 kasus kematian di seluruh dunia akibat kanker serviks pada wanita dengan usia 15 - 44 tahun. Menurut data dari Kementrian Kesehatan Republik Indonesia (Kemeskes RI) pada tahun 2013, kejadian kanker serviks di Indonesia sebesar 0,8\% [2]. Jawa Barat merupakan provinsi dengan jumlah penduduk terbanyak di Indonesia yaitu 40.737 .594 orang, dimana penduduk wanita sebanyak 49,5\% dan terdapat angka kejadian tumor/kanker $0,5 \%$ estimasi kejadian 26/100.000 wanita atau sekitar 5200 kasus [3]. Estimasi jumlah kasus kanker serviks di Jawa Barat pada tahun 2013 adalah 15.365 orang [4].

Beberapa komponen dalam pengendalian kanker secara Nasional adalah, Usaha pencegahan yaitu meminimalisasi faktor penyebab kanker atau promosi gaya hidup sehat, deteksi dini dan skrining dalam hal ini dapat menurunkan angka kematian karena ditemukan dalam stadium yang lebih awal, Diagnosis dan pengobatan, Perawatan paliatif, Monitoring dan surveilens, dan Riset dan koordinasi program [5]. Untuk negara-negara berkembang (Indonesia), hal - hal penting yang menjadi pertanyaan dalam pengendalian kanker serviks adalah melakukan implementasi dan mempertahankan kelanggengan program deteksi dini yang berbasis sitologik konvensional, dimana terkendala pada teknisi dan infrastruktur yang dibutuhkan, bagaimana mendapatkan cakupan yang memenuhi target dari program deteksi dini, dan bagaiman mengatasi hambatan logistik tersebut[5].

Pemilihan IVA sebagai modalitas skrining di Indonesia dilakukan dengan mempertimbangkan kurangnya tenaga skriner maupun sitologis. Tenaga tersebut diperlukan jika memilih skrining berbasis sitologik. Selain itu, IVA tidak memerlukan infrastruktur yang terlalu sulit, murah, mudah, dan cepat diketahui hasilnya. Metoda skrining ini memang dapat memberikan hasil positif palsu yang cukup besar karena sangat subjektif dari penilaian pelaksana [2], [5]. Untuk menekan angka positif palsu, dikembang suatu aplikasi berbasis pengolahan citra digital dalam deteksi dini kanker serviks.

Pada tahap awal dan pre-cancer, penderita kanker serviks tidak mengalami gejala - gejala khusus. Perubahan kanker dari tahap pre-cancer menjadi invasive cancer membutuhkan waktu sepuluh sampai dua puluh tahun. Pada tahap pre-cancer, penderita masih dapat ditangani dan disembuhkan. Namun, setelah menjadi invasive cancer barulah terasa gejalanya dan sudah terlambat untuk ditangani sehingga tingkat kematian yang tinggi akibat kanker serviks secara global mencapai 52\%. Berbagai upaya untuk mengatasi hal tersebut telah banyak dilakukan yang di antaranya adalah dengan program skrining dan pengobatan yang efektif. Program skrining 
kanker adalah pengujian untuk prakanker dan kanker di kalangan perempuan yang tidak memiliki gejala dan mungkin merasa sangat sehat. Melalui program ini, pra-kanker dapat terdeteksi secara dini, Salah satu metode skrining pra-kanker serviks adalah Inspeksi Visual Asam Asetat (IVA). IVA memiliki sensitivitas yang hampir sama dengan sitologi serviks (pap smear) sehingga dapat menjadi metode skrining yang paling efektif di Indonesia.

Umumnya, tenaga ahli kesehatan tidak menggunakan alat bantu visual khusus dalam melakukan pengamatan hasil tes IVA [6] sehingga hasil diagnosis tenaga ahli akan bersifat subjektif. Untuk mengatasi hal tersebut berbagai penelitian telah dilakukan seperti pada penelitian [7] dimana Acetowhite Epithelium Zone (AEZ) yang merupakan lesi IVA positif (lesi kanker) dapat dideteksi secara semi-otomatis dengan menggunakan metode registered ratio image. Beberapa penelitian deteksi kanker serviks dengan pengolahan citra digital dilakukan dengan artificial intelligence baik dengan platform machine learning [8]-[10] maupun dengan deep learning [11], [12]. Untuk meningkatkan performa system deteksi kanker serviks dengan pengolahan citra digital telah dilakukan dengan meningkatkan kualitas citra input [13] dan optimasi algoritma klasifikasi system [14], [15]. Akhirnya, penelitian paling popular terkait system deteksi kanker serviks melalui pengolahan citra hasil inspeksi visual asam asetat ini adalah dengan menggunakan platform smartphone atau mobile telemedicine [9], [10], [12], [16]-[22].

\section{METODE PENELITIAN}

Perancangan sistem deteksi pra-kanker serviks dibuat melalui dua proses utama yaitu proses deteksi centroid endoserviks dan deteksi lesi-prakanker serviks setelah pengolesan asam asetat. Secara umum, proses kerja sistema dapat dilihat pada gambar 1.

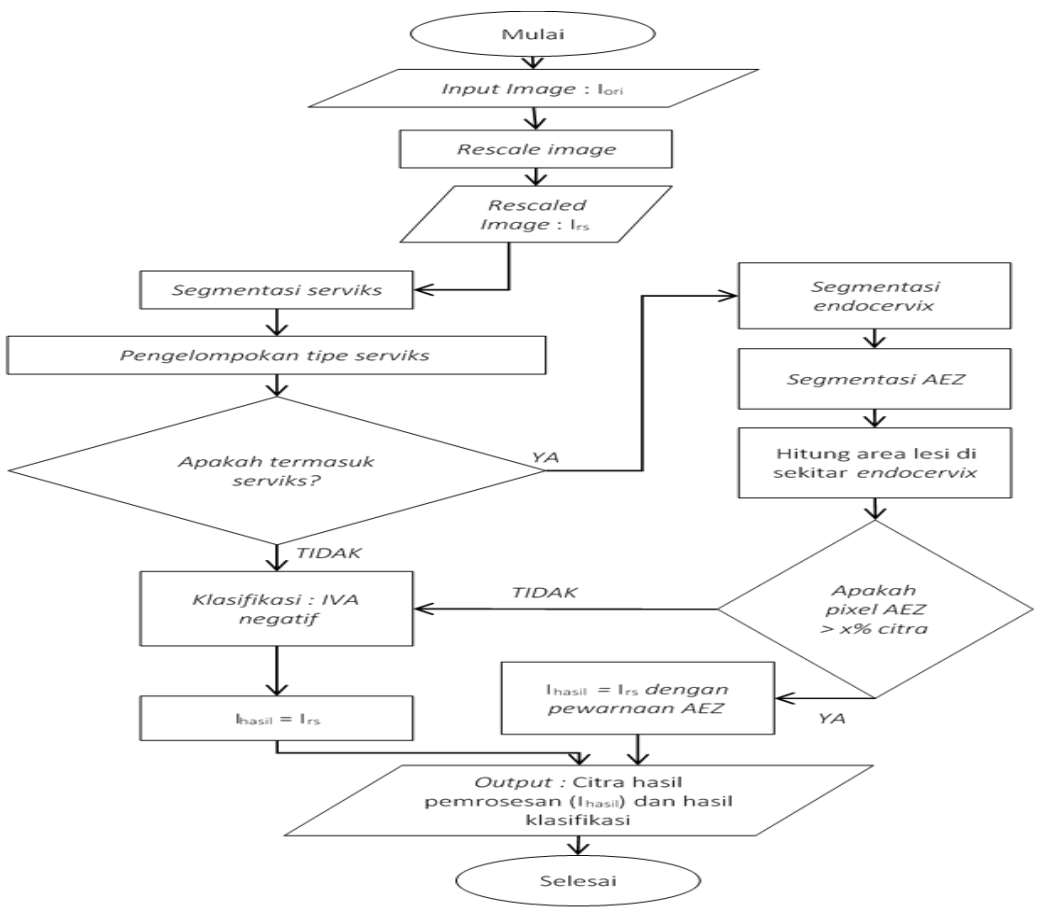

Gambar 1. Diagram Proses Sistem

\subsection{Data Penelitian}

Pada penelitian ini, data yang digunakan adalah data kesehatan dari hasil kerjasama penelitian dengan divisi obstetric dan ginekologi Fakultas Kedokteran Universitas Padjadjaran. Data yang digunakan pada penelitian ini adalah citra serviks yang telah dilakukan tes IVA sebanyak 72 citra dengan 38 citra IVA positif dan 34 IVA negatif. Semua data telah dilakukan 
verifikasi oleh tenaga ahli dokter spesialis ginekologi dengan keterangan dan informasi-informasi penting terkait citra IVA tersebut. Dalam sistem, selanjutnya citra-citra tersebut dipisah menjadi 2 kelas. Kelas pertama berisi informasi lesi IVA negatif dan kelas kedua berisi informasi lesi IVA positif. Selanjutnya, kedua kelas tersebur dicari ciri - ciri khusus dari lesinya untuk IVA positif dan IVA negatif pada ruang warna RGB maupun HSV. Dari nilai RGB dan HSV dilakukan perhitungan regresi linear untuk mencari nilai threshold kriteria lesi IVA positif dan negatif.

\subsection{Deteksi Endocervix}

Proses deteksi endocervix akan dilakukan setelah mendapatkan citra hasil rescale resolusi citra menjadi 256x256. Pendeteksian endocervix dilakukan menggunakan metode segmentasi dengan thresholding pada model ruang warna. Threshold didapatkan dari penentuan nilai beberapa pixel objek endocervix. Ruang warna yang digunakan untuk deteksi dapat berupa kombinasi antara model HSV dan model RGB. Hasil dari proses deteksi endocervix berupa citra biner, warna putih (bernilai 1) untuk daerah yang terdeteksi AEZ dan hitam (bernilai 0) untuk lainnya. Diagram alir sistem deteksi endocervix dapat dilihat pada gambar 2.

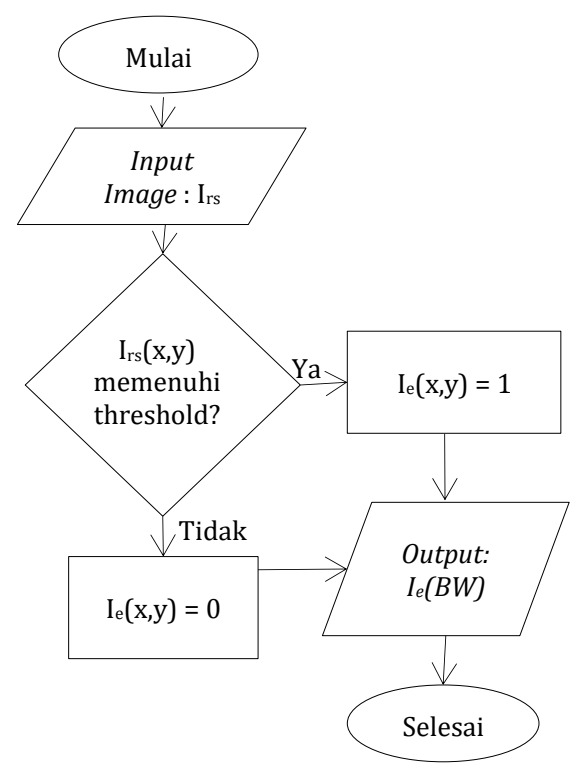

Gambar 2 Diagram Alir Segmentasi Endocervix

\subsection{Deteksi Acetowhite Epithelium Zone}

Proses deteksi AEZ akan dilakukan setelah mendapatkan citra hasil rescale resolusi citra menjadi 256x256. Pendeteksian AEZ dilakukan menggunakan metode segmentasi dengan thresholding pada model ruang warna. Threshold didapatkan dari hasil regresi linier beberapa citra AEZ. Ruang warna yang digunakan untuk deteksi dapat berupa kombinasi antara model HSV dan model RGB. Hasil dari proses deteksi AEZ berupa citra biner, warna putih (bernilai 1) untuk daerah yang terdeteksi AEZ dan hitam (bernilai 0) untuk lainnya. Diagram alir sistem deteksi AEZ dapat dilihat pada gambar 3. 


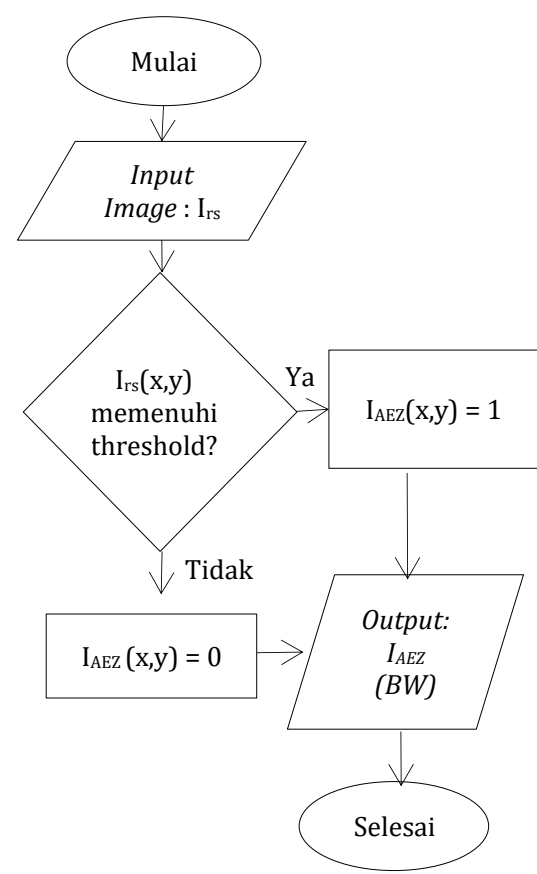

Gambar Error! No text of specified style in document.

\section{HASIL DAN PEMBAHASAN}

Pengujian sistem deteksi lesi pra kanker pada citra hasil tes IVA dilakukan dengan melalui dua skema pengujian yaitu pengujian área lesi putih dan letak centroide pada endocerviks. Pada pengujian ini, area lesi pra-kanker yang dikuantifikasi dengan warna kuning pada piksel diuji ketepatannya oleh tenaga ahli kesehatan yaitu dokter spesialis obstetric dan ginekologi. Dari 72 citra, didapatkan hasil verifikasi ketepatan area lesi pra-kanker 59 citra sesuai dan 13 citra tidak sesuai. Dari hasil tersebut didapatkan nilai kesesuaian atau akurasi deteksi area lesi prakanker sebesar 81,94\%. Citra hasil deteksi lesi pra-kanker dapat dilihat pada gambar 2.

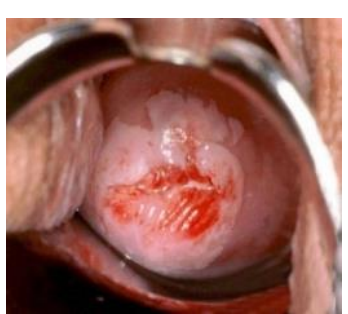

(a)

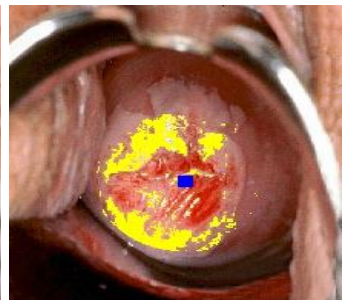

(b)

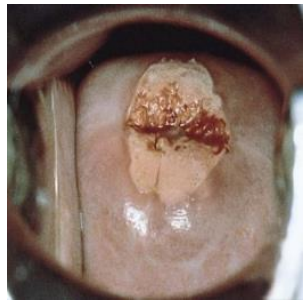

(c)

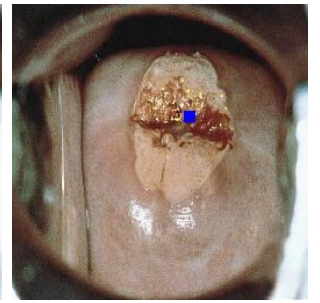

(d)

Gambar 2. Deteksi Area Lesi Pra-kanker Serviks. Warna biru pada citra mengindikasikan centroid dari endocervix sedangkan warna kuning merupakan daerah yang terindikasi sebagai lesi IVA positif. (a) dan (c) citra asli serviks (b) citra serviks dengan hasil sistem deteksi area lesi pra-kanker (d) Citra serviks hasil deteksi sistem tanpa area lesi pra-kanker

Selain penilaian akurasi system deteksi lesi pra-kanker, dilakukan pula perhitungan nilai sensitivitas dan spesifisitas system. Dari 72 data citra terdapat 38 citra IVA positif dan 34 citra IVA negative. Hasil uji sistem didapatkan hasil deteksi 32 citra negatif benar, 6 positif palsu, 27 citra positif benar, dan 7 negatif palsu. Berdasarkan hasil tersebut, maka perhitungan sensitivitas dan spesifisitas sistemnya adalah $79,41 \%$ dan $84,21 \%$ secara terurut. 
Berdasarkan hasil analisa, kesalahan deteksi lesi pra-kanker dan centroid endoserviks pada sistem diakibatkan oleh faktor cahaya. Setidaknya ada tiga jenis factor pencahayaan yang mengakibatkan kesalahan deteksi pada sistem yaitu pantulan cahaya yang muncul akibat adanya cairan pada permukaan serviks, adanya bayangan akibat pencahayaan yang tidak sesuai, dan intensitas cahaya yang kurang. Faktor pantulan cahaya pada permukaan serviks menyebabkan permukaan serviks berwarna putih, hal ini menyebabkan sistem seringkali mendeteksinya sebagai lesi putih pra-kanker. Sedangkan akibat factor bayangan dan intensitas cahaya yang kurang menyebabkan perubahan warna pada piksel citra sehingga tidak masuk kualifikasi nilai piksel yang sesuai dengan threshold lesi pra-kanker pada sistem. Faktor eksternal yang mempengaruhi performa pengolahan citra pada sistem deteksi lesi pra-kanker dan sentroid endoserviks adalah tipe dan metode pengambilan data citra yang bervariasi. Variasi ini dihasilkan dari jenis kamera, intensitas cahaya saat pengambilan citra, maupun pigmen serviks pasien yang berbeda. Hal ini menyebabkan lesi iva positif maupun lesi iva positif palsu tidak dapat terdeteksi dengan baik.

\subsection{Pengaruh Kecerahan Citra}

Berdasarkan hasil pengujian sebelumnya, factor utama yang mempengaruhi performa sistem adalah kualitas citra yang sangat ditentukan oleh cahaya. Pada pengujian ini citra diubah tingkat kecerahannya. Konfigurasi kecerahan citra dilakukan dengan mengubah citra ke ruang warna HSV. Citra HSV kemudian dikalikan dengan nilai luminance 0,8 (kecerahan -20\%); 0,9 (kecerahan -10\%); 1,1 (kecerahan $+10 \%$ ); dan 1,2 (kecerahan $+20 \%$ ). Luminansi pada HSV merupakan upaya pendekatan konfigurasi citra terhadap kecerahan atau intensitas pencahayaan. Setelah nilai luminance dikalikan dengan nilai tersebut, citra pada ruang warna HSV tersebut dikonversi kembali ke ruang warna RGB untuk kemudian diproses oleh sistem. Hasil konfigurasi tingkat kecerahan citra dapat dilihat pada gambar 3.

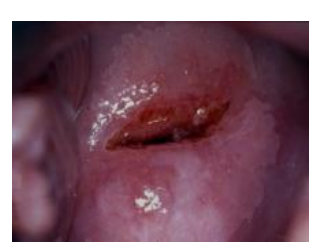

(a)

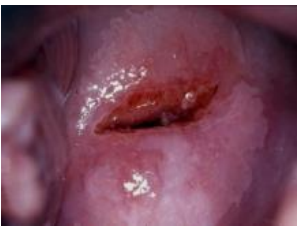

(b)

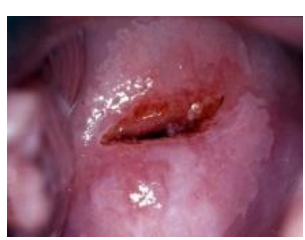

(c)

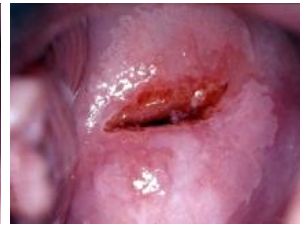

(d)

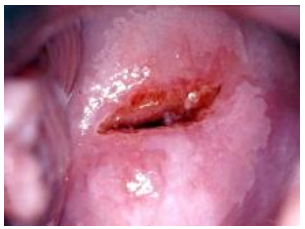

(e)

Gambar 3. Perbandingan tingkat kecerahan citra. (a) luminansi 0,8 (b) luminansi 0,9 (c) Citra normal (d) Luminansi 1,1 (e) Luminansi 1,2

Pengujian sistem deteksi lesi pra-kanker serviks dilakukan pada seluruh citra hasil konfigurasi luminance dan dihasilkan tingkat akurasi tertinggi pada kecerahan $0 \%$ yaitu $81,94 \%$. Pada tingkat kecerahan citra $-10 \%$, akurasi sistem turun sebesar 6,94\% sedangkan pada tingkat kecerahan -20 akurasi sistem turun sebesar 4,17\% dibanding akurasi tanpa tanpa perubahan luminansi. Penurunan akurasi dialami pula saat dilakukan peningkatan tingkat kecerahan citra. Pada tingkat kecerahan +10 akurasi sistem turun sebesar 6,94\% sedangkan pada tingkat kecerahan +20 akurasi sistem turun sebesar 11,60\%. Perubahan tingkat kecerahan citra menyebabkan sistem dapat mendeteksi lesi pra-kanker dengan baik namun tidak akurat untuk beberapa citra yang semula dapat terdeteksi dengan baik sebelum dilakukan perubahan tingkat kecerahannya.

Pada pengujian nilai sensitivitas, sistem mampu bekerja secara optimal ketika pengujian pada citra asli. Hal tersebut didapatkan dari nilai sensitivitas dan spesifisitas yang paling tinggi terjadi pada pengujian citra asli. Nilai sensitivitas sistem menurun secara signifikan ketika tingkat kecerahan citra uji dinaikkan. Saat tingkat kecerahan dinaikkan sebesar 10\%, nilai sensitivitas sistem turun sebesar $14,70 \%$. Saat tingkat kecerahan dinaikkan sebesar $20 \%$, nilai sensitivitas sistem turun sebesar $26,47 \%$ dari pengujian citra asli. Saat tingkat kecerahan diturunkan sebesar $10 \%$, nilai sensitivitas sistem turun sebesar 2,94\%. Ketika tingkat kecerahan diturunkan sebesar 
$20 \%$, nilai sensitivitas sistem turun sebesar $5,89 \%$ dari pengujian citra asli. Penurunan nilai sensitivitas ketika tingkat kecerahan citra uji dinaikkan disebabkan oleh beberapa faktor. Faktor utamanya adalah lesi iva positif yang seharusnya terdeteksi, dianggap sebagai pantulan cahaya oleh sistem. Hal dapat itu terjadi karena warna lesi iva positif berubah menjadi warna putih seperti pantulan cahaya. Faktor penyebab lainnya dikarenakan terjadinya perubahan warna pada ruang RGB sehingga tidak dapat dicakup oleh threshold yang sudah ditetapkan oleh sistem. Penyebab penurunan nilai sensitivitas ketika tingkat kecerahan citra uji diturunkan adalah endocervix yang tidak dapat terdeteksi dengan baik. Karena syarat untuk menjadi IVA positif adalah lesi prakanker berada di sekeliling endocervix, ruang lingkup pemeriksaan lesi IVA akan berkurang sehingga sistem tidak mendeteksi adanya lesi IVA positif.

Pada pengujian nilai spesifisitas sistem cenderung stabil saat tingkat kecerahan citra uji ditingkatkan. Saat tingkat kecerahan citra uji dinaikkan hingga 20\%, nilai spesifisitas sistem konstan pada $84,21 \%$. Sedangkan ketika tingkat kecerahan citra uji diturunkan sebesar $10 \%$, nilai spesifisitas sistem turun sebesar $10,53 \%$. Kemudian saat tingkat kecerahan citra uji diturunkan sebesar $20 \%$, nilai spesifisitas sistem turun sebesar 2,64\% dari pengujian citra asli. Penurunan nilai spesifisitas dikarenakan sistem salah melakukan pengklasifikasian jenis warna serviks. Hal tersebut memengaruhi proses penglasifikasian jenis serviks, sehingga threshold yang digunakn untuk mendeteksi endocervix maupun lesi iva berbed Perolehan hasil pengujian system dapat dilihat pada tabel 1 .

Tabel 1. Hasil Data Pengujian Pengaruh Kecerahan pada Citra Uji

\begin{tabular}{|l|c|c|c|c|c|}
\hline \multirow{3}{*}{ Keterangan } & \multicolumn{5}{|c|}{ Jumlah Citra } \\
\cline { 2 - 6 } & \multicolumn{5}{|c|}{ Kecerahan (\%) } \\
\cline { 2 - 6 } & -20 & -10 & 0 & +10 & +20 \\
\hline Hasil uji benar & 56 & 54 & 59 & 54 & 50 \\
\hline Hasil uji salah & 16 & 18 & 13 & 18 & 22 \\
\hline Positif benar & 25 & 26 & 27 & 22 & 18 \\
\hline Positif palsu & 7 & 8 & 7 & 10 & 14 \\
\hline Negatif benar & 31 & 28 & 32 & 32 & 32 \\
\hline Negatif palsu & 7 & 10 & 6 & 6 & 6 \\
\hline Akurasi (\%) & $\mathbf{7 7 , 7 8}$ & $\mathbf{7 5 , 0 0}$ & $\mathbf{8 1 , 9 4 \%}$ & $\mathbf{7 5}$ & $\mathbf{6 9 , 4 4}$ \\
\hline Sensitivitas (\%) & $\mathbf{7 3 , 5 2}$ & $\mathbf{7 6 , 4 7}$ & $\mathbf{7 9 , 4 1 \%}$ & $\mathbf{6 4 , 7 1}$ & $\mathbf{5 2 , 9 4}$ \\
\hline Spesifisitas (\%) & $\mathbf{8 1 , 5 7}$ & $\mathbf{7 3 , 6 8}$ & $\mathbf{8 4 , 2 1 \%}$ & $\mathbf{8 4 , 2 1}$ & $\mathbf{8 4 , 2 1}$ \\
\hline
\end{tabular}

\subsection{Pengaruh Blurring Noise terhadap Sistem}

Blurring noise merupakan salah satu gangguan pada citra digital yang mengakibatkan gambar menjadi kurang jelas dan tidak tajam. Pada penelitian ini sistem deteksi pra-kanker serviks diuji untuk memproses data citra dengan blurring noise. Dengan pengujian ini didapatkan sejauh mana sistem memiliki toleransi performa dengan akurasi yang baik. Selanjutnya, pada skema pengujian ini data diolah dengan menambahkan blurring noise. Data disaring menggunakan low pass filter dengan cara mengonvolusikan citra asli dengan kernel mean ukuran $3 \times 3,5 \times 5,7 \times 7$, dan 9x9. Citra dengan gangguan blurring dapat dilihat pada gambar 6 .

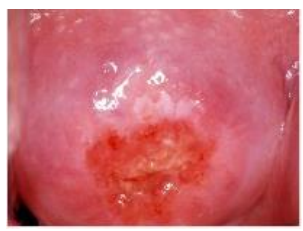

(a)

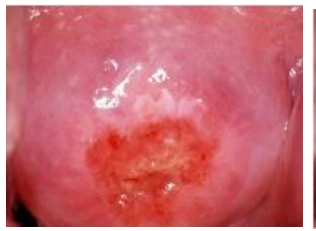

(b)

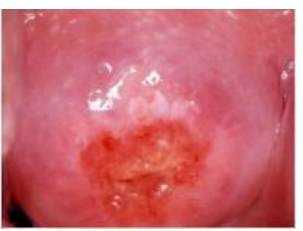

(c)

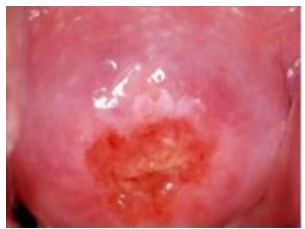

(d)

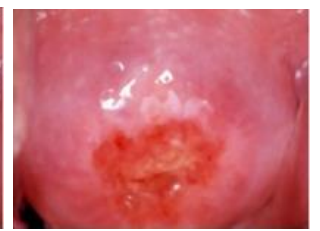

(e) 
Gambar 6. Citra Serviks dengan gangguan blurring. (a) Citra Normal (b) Citra dengan median filter kernel 3x3 (c) Citra dengan median filter kernel 5x5 (d) Citra dengan median filter kernel 7x7 Citra dengan median filter kernel 9x9

Berdasarkan hasil pengujian citra asli, sistem mampu mendeteksi $81,94 \%$ benar. Selanjutnya akurasi sistem menurun pada citra yang telah diberi gangguan blurring secara bertahap dari 79,16\% pada kernel 3x3 hingga 77,77\% pada citra terfilter dengan mean kernel 9x9. Bersdasarkan hasil tersebut, semakin besar dimensi mean kernel maka performansi sistem (akurasi) akan menurun. Semakin besar dimensi mean kernel, maka perubahan nilai yang terjadi pada tiap piksel citra akan semakin besar. Hal tersebut menyebabkan karakteristik nilai lesi iva positif pada piksel berubah. Sedangkan, batas ambang lesi iva positif sudah ditetapkan di awal dengan acuan citra yang tidak terkena efek low pass filter. Pada akhirnya sistem akan salah deteksi citra dikarenakan perubahan nilai piksel tersebut.

Pada pengujian sistem menggunakan parameter nilai sensitivitas dan spesifisitas umumnya didapatkan pola semakin besar dimensi mean kernel, semakin kecil nilai sensitivitasnya dimana sensitivitas sistem memiliki niliai yang sama tinggi dengan citra asli pada citra dengan mean filter 3x3 sebesar 79,41\%. Lain halnya dengan spesifisitas sistem, pola linear nilainya tidak cukup terlihat seperti pada akurasi dan sensitivitas. Sistem memiliki nilai spesifitas yang tinggi untuk pengolahan citra dengan mean $5 \times 5$ dan $7 \times 7$ sebesar $81,57 \%$ dan nilai yang sama pada citra dengan mean $3 \times 3$ dan 9x9 sebesar 78,94\%. Berdasarkan hasil pengujian sistem, citra lesi negatif palsu lebih sering terjadi dikarenakan endocervix yang terdeteksi lebih kecil, sehingga lesi IVA yang dihitung semakin kecil dan mengakibatkan lesi pra-kanker tidak terdeteksi. Sedangkan citra lesi positif palsu sering terjadi karena efek dari noise cahaya yang melebar sehingga citra lesi terdeteksi sebagai lesi IVA positif palsu. Hasil pengujian sistem prakanker serviks terhadap parameter akurasi, sensitivitas, dan spesifisitas dengan input citra terfilter mean kernel dapat dilihat pada tabel 2 .

Tabel 2. Sensitivitas dan Spesifisitas Sistem pada Citra Terfilter Mean Kernel

\begin{tabular}{|c|c|c|c|c|}
\hline No. & Keterangan & Akurasi (\%) & Sensitivitas (\%) & Spesifisitas (\%) \\
\hline $\mathbf{1}$ & Citra asli & 81,94 & 79,41 & 84,21 \\
\hline $\mathbf{2}$ & Citra terfilter $(3 \times 3)$ & 79,16 & 79,41 & 78,94 \\
\hline $\mathbf{3}$ & Citra terfilter $(5 \times 5)$ & 79,16 & 76,47 & 81,57 \\
\hline $\mathbf{4}$ & Citra terfilter $(7 \times 7)$ & 77,77 & 73,52 & 81,57 \\
\hline $\mathbf{5}$ & Citra terfilter $(9 \times 9)$ & 77,77 & 76,47 & 78,94 \\
\hline
\end{tabular}

\section{KESIMPULAN DAN SARAN}

Berdasarkan hasil pengujian dan analisis system deteksi pra-kanker serviks dapat disimpulkan bahwa citra lesi pra-kanker serviks dapat dikuantifikasi dengan pengolahan citra digital secara optimal dan mampu membedakan citra serviks yang terindikasi IVA positif maupun IVA negatif. Hal tersebut dapat terlihat dari nilai akurasi, sensitivitas, dan spesifisitas yang cukup tinggi dengan angka sekitar $80 \%$. Namun demikian hasil pengujian dan analisis pun membuktikan bahwa pengambilan citra hasil inspeksi visual asam asetat harus diikuti dengan standard pengambilan gambar yang sesuai terutama perihal ketajaman dan pencahayaan yang meliputi tingkat kecerahan, pantulan cahaya, bayangan dari efek pencahayaan yang kurang tepat. Investigasi lebih lanjut mengenai standarisasi pengambilan gambar serviks perlu dilakukan untuk mendapatkan nilai performa sistem deteksi pra-kanker serviks yang lebih optimal.

\section{DAFTAR PUSTAKA}


[1] Badan Penelitian dan Pengembangan Kesehatan, "Riset Kesehatan Dasar 2013," Ris. Kesehat. Dasar 2013, 2013.

[2] A. Aprianti, M. Fauza, and A. Azrimaidalisa, "Faktor yang Berhubungan dengan Deteksi Dini Kanker Serviks Metode IVA di Puskesmas Kota Padang," J. Promosi Kesehat. Indones., 2018, doi: 10.14710/jpki.14.1.68-80.

[3] F. \& S. M. A. Wulandari, "Hubungan Tingkat Pengetahuan dan Sikap dengan Perilaku Pemeriksaan SADARI Mahasiswi," Pros. Semin. Nas. IKAKESMADA "Peran Tenaga Kesehat. dalam Pelaks. SDGs," 2017.

[4] F. Herlana, I. M. Nur, and W. Purbaningsih, "Karakteristik Pasien Kanker Serviks berdasar atas Usia, Paritas, dan Gambaran Histopatologi di RSUD Al-Ihsan Bandung," Bandung Meet. Glob. Med. Heal., 2017.

[5] B. Dwipoyono, "Kebijakan Pengendalian Penyakit Kanker ( Serviks ) di Indonesia," Indones. J. Cancer, 2009.

[6] S. Mustafa, S. Adeshina, M. Dauda, and W. Soboyejo, "Classification of cervical cancer tissues using a novel low cost methodology for effective screening in rural settings," in Proceedings of the 11th International Conference on Electronics, Computer and Computation, ICECCO 2014, 2014, doi: 10.1109/ICECCO.2014.6997552.

[7] J. Liu, L. Li, and L. Wang, "Acetowhite region segmentation in uterine cervix images using a registered ratio image," Comput. Biol. Med., 2018, doi: 10.1016/j.compbiomed.2017.12.009.

[8] A. Kanitkar, R. Kulkarni, V. Joshi, Y. Karwa, S. Gindi, and G. Kale, "Automatic Detection of Cervical Region from VIA and VILI Images using Machine Learning," in Proceedings - 22nd IEEE International Conference on Computational Science and Engineering and 17th IEEE International Conference on Embedded and Ubiquitous Computing, CSE/EUC 2019, 2019, doi: 10.1109/CSE/EUC.2019.00010.

[9] J. K. Bae et al., "Quantitative screening of cervical cancers for low-resource settings: Pilot study of smartphone-based endoscopic visual inspection after acetic acid using machine learning techniques," JMIR mHealth uHealth, 2020, doi: 10.2196/16467.

[10] G. Sapiro et al., "Image processing and machine learning techniques to automate diagnosis of Lugol's iodine cervigrams for a low-cost point-of-care digital colposcope," 2018, doi: $10.1117 / 12.2282792$.

[11] L. Hu et al., "An Observational Study of Deep Learning and Automated Evaluation of Cervical Images for Cancer Screening," J. Natl. Cancer Inst., 2019, doi: 10.1093/jnci/djy225.

[12] L. Hu et al., "Deep learning-based image evaluation for cervical precancer screening with a smartphone targeting low resource settings - Engineering approach," in Proceedings of the Annual International Conference of the IEEE Engineering in Medicine and Biology Society, EMBS, 2020, doi: 10.1109/EMBC44109.2020.9175863.

[13] V. Kudva, K. Prasad, and S. Guruvare, "Detection of Specular Reflection and Segmentation of Cervix Region in Uterine Cervix Images for Cervical Cancer Screening," IRBM, 2017, doi: 10.1016/j.irbm.2017.08.003.

[14] V. Kudva and K. Prasad, "Pattern classification of images from acetic acid-based cervical cancer screening: A review," Critical Reviews in Biomedical Engineering. 2018, doi: 10.1615/CritRevBiomedEng.2018026017.

[15] N. Thendral and D. Lakshmi, "Performance comparison of SVM classifier based on kernel functions in colposcopic image segmentation for cervical cancer," in Lecture Notes in Computational Vision and Biomechanics, 2019.

[16] K. E. Quinley et al., "Use of mobile telemedicine for cervical cancer screening," $J$. Telemed. Telecare, 2011, doi: 10.1258/jtt.2011.101008.

[17] C. Gallay et al., "Cervical cancer screening in low-resource settings: A smartphone image application as an alternative to colposcopy," Int. J. Womens. Health, 2017, doi: 
10.2147/IJWH.S136351.

[18] B. D. Grant et al., "A mobile-phone based high-resolution microendoscope to image cervical precancer," PLoS One, 2019, doi: 10.1371/journal.pone.0211045.

[19] C. Millien, M. C. Jean-Baptiste, G. Manite, and D. Levitz, "Remote quality assurance in cervical cancer screening in low resource settings using a handheld smartphone-based colposcope," in Optics and Biophotonics in Low-Resource Settings, 2015, doi: 10.1117/12.2086377.

[20] S. A. Monsur, S. A. Adeshina, S. Sud, and W. O. Soboyejo, "A mobile-based image analysis system for cervical cancer detection," in 2017 13th International Conference on Electronics, Computer and Computation, ICECCO 2017, 2018, doi: 10.1109/ICECCO.2017.8333312.

[21] S. Drishti et al., "Feasibility of implementing cervical cancer screening program using smartphone imaging as a training aid for nurses in rural India," Public Health Nurs., 2018.

[22] R. Bagga et al., "Feasibility of Using Mobile Smartphone Camera as an Imaging Device," J Postgr. Med Edu Res, 2016, doi: 10.5005/jp-journals-10028-1196. 